\title{
Passiflora foetida yielding and nutritional composition
}

\author{
Danilo Fernandes da Silva Filho ${ }^{1}$, Manoel Ronaldo Aguiar Batista ${ }^{2}$, Jaime Paiva Lopes Aguiar ${ }^{3}$, \\ Francisco Manoares Machado ${ }^{4}$, José Nilton Rodrigues Figueiredo, \\ César Augusto Ticona-Benavente ${ }^{6}$
}

\begin{abstract}
Even though wild maracuja (Passiflora foetida) is cultivated in tropical areas, no thorough investigation regarding its yield or nutritional composition is easily available. This paper aims to estimate its fruit yield, using four staking systems; as well as determine both its fruit pulp and peel chemical composition. The treatments used were $\mathrm{T} 1=$ No staking, $\mathrm{T} 2=\mathrm{A}$ vertical rod, $\mathrm{T} 3=\mathrm{A}$ horizontal rod, $60 \mathrm{~cm}$ from the ground, T4= Two horizontal poles, 60 and $120 \mathrm{~cm}$ from the ground, and T5= Using horizontal trellises, $80 \mathrm{~cm}$ above ground. The findings showed T5, T4, $\mathrm{T} 3, \mathrm{~T} 2$ and $\mathrm{T} 1$ to yield $1.40,1.05,0.66,0.40$ and 0.35 tons of fruits per hectare, respectively. In general, the fruit pulp held higher nutrient content than that of fruit peel. The pulp presented $2.6 \%$, $4.5 \%$ and $24.3 \%$ protein, lipids and carbohydrates, respectively. We conclude this genotype to bear low yielding potential, which may be lightly enhanced when cultivated using horizontal trellises. Index terms: Physicochemical composition, horizontal trellises, Amazonian fruit.
\end{abstract}

\section{Composição nutricional e produtividade de Passiflora foetida}

Corresponding author: cesar.benavente@gmail.com

Received: November 08, 2018 Accepted: February 05, 2019

Copyright: All the contents of this journal, except where otherwise noted, is licensed under a Creative Commons Attribution License.
Resumo - Apesar de que o maracujaí (Passiflora foetida) é cultivado nos trópicos, há falta de trabalhos relacionados à sua produtividade e composição nutricional. O objetivo deste trabalho foi estimar a produtividade desta espécie utilizando quatro sistemas de tutoramento, assim como determinar a composição química da polpa e da pele, separadamente. Os tratamentos utilizados foram: $\mathrm{T} 1=$ sem tutoramento; $\mathrm{T} 2=$ uma vara vertical; $\mathrm{T} 3=$ uma vara horizontal a $60 \mathrm{~cm}$ do solo; $\mathrm{T} 4=$ duas varas horizontais a 60 e $120 \mathrm{~cm}$ do solo, e T5= usando uma latada a $80 \mathrm{~cm}$ do solo. Resultados mostraram que T5; T4; T3;T2 e T1 produziram 1,$4 ; 1,05 ; 0,66 ; 0,40$ e $0,35 \mathrm{t}$ de frutos por hectare, respectivamente. Em geral, a polpa da fruta teve teores mais elevados de nutrientes que a pele. A polpa apresentou $2.6 \%, 4.5 \%$ e $24.3 \%$ de proteínas, lipídeos e carboidratos, respectivamente. Portanto, este genótipo tem baixo potencial produtivo, mas pode ser melhorado levemente utilizando uma latada.

Termos para indexação: Composição físico-química, latada, fruto amazônico.

\section{(cc) EY}

${ }^{1} \mathrm{PhD}$ in Botanics, researcher at Instituto Nacional de Pesquisas da Amazônia Manaus-AM. E-mail:danilo@inpa.gov.br (ORCID 0000-0001-56379521)

${ }^{2}$ Agricultural engineer, field assistant at Instituto Nacional de Pesquisas da Amazônia Manaus-AM. E-mail: ronaldo@inpa.gov.br(ORCID 00000002-3114-3560)

${ }^{3}$ Specialist in nutrition and food Science at Instituto Nacional de Pesquisas da Amazônia Manaus-AM. E-mail: jaguiar@inpa.gov.br ${ }^{(0 R C I D}$ 00000003-4534-7705)

${ }^{4}$ Specialist in wood industry, researcher at Instituto Nacional de Pesquisas da Amazônia Manaus-AM. E-mail: manoares@inpa.gov.br ${ }^{\text {(ORCID }}$ 0000-0002-2525-7799)

${ }^{5}$ Agricultural engineer, field assistant at Instituto Nacional de Pesquisas da Amazônia Manaus-AM. E-mail: agronilton@yahoo.com.br ${ }^{\text {ORCID }}$ 0000-0001-7600-0064)

${ }^{6} \mathrm{PhD}$ in genetics and plant breeding, researcher at Instituto Nacional de Pesquisas da Amazônia Manaus-AM. E-mail:cesar.benavente@gmail. COM (ORCID 0000-0002-3636-2324) 
Passiflora foetida grows wild in the Amazonian region. Agronomical and nutritional composition investigations must be undertaken so as to ascertain its commercial potential.

Genus Passiflora L. comprises about 524 species, being 500 from the Americas (FEUILLET; MACDOUGAL, 2007). South America holds 95\% of Passiflora species (YOCKTENG et al., 2011). In spite of the high biodiversity shown by this genus, $95 \%$ of the Brazilian area being employed for its cultivation is just covered with yellow passion fruit (P. edulis f. flavicarpa) (MELETTI; BRÜCKNER, 2001). The annual mean fruit production from 2010 to 2014 showed to be 856,000 tons in 59,000 hectares, with mean fruit yield of $14.5 \mathrm{t} \mathrm{ha}^{-1}$ (IBGE, 2014).

The species $P$. foetida also presents a genetic diversity (BEENA; BEEVY, 2015), and in general it is considered to be a medicinal weed. Ethnobotanical studies pointed its leaves and fruits in treatment of asthma, icterus, skin disorders, inflammation, digestion disorders, stomachache, constipation, flatulence, dizziness (WAGNER et al., 1990), and anti-cancer activity (PURICELLI et al., 2003).

This wild species releases an unpleasant smell. Its small sweet orange fruits $(<2 \mathrm{~cm}$ of diameter,

) taste like commercial fruits such as 'Granadilla' ( $P$. ligularis) or 'Maracujá do Mato' ( $P$. cincinnata). Therefore, its yielding and cultivation methods should be determined in order for it to be marketed either in natura or processed.

As passion fruit is cultivated using staking systems (COSTA et al., 2008) this paper aims to determine which staking system may lead to a greater fruit yield. In addition, it was estimated both fruit peel and pulp chemical composition.

Mature fresh fruit were collected from a wild maracuja, growing alongside Benjamin Constant to Atalaia do Norte city roadway $\mathrm{Km} 12$ (4' $26^{\prime} \mathrm{S}$ and $70^{\circ}$ $\left.06^{\prime} \mathrm{W}\right)$. The fruits were washed in water, next the seeds were winkled out. The seeds with aril were fermented in water for $72 \mathrm{~h}$ at ambient temperature. Then, they were dried for $48 \mathrm{~h}$ at room temperature $\left(28^{\circ} \mathrm{C}\right)$. Finally, the seeds were kept in glass hermetic flasks at $5.6^{\circ} \mathrm{C}$ and $30 \%$ of relative moisture.

The staking systems experiment was carried out at experimental horticultural station from Instituto Nacional de Pesquisas da Amazônia (INPA) located at Km 14 on the AM-10 highway in Manaus. The soil was red-yellow Oxisol. The local climate is 'Af' type, with mean annual $2450 \mathrm{~mm}$ rainfall (ALVARES et al., 2013).

The sowing was done on December 15th, 2013, using Styrofoam trays with 72 cells and sterile substrate (50\% of soil and $50 \%$ of organic compost). This sterilization was done using $0.5 \% \mathrm{HCl}$. After two weeks, seedlings with two true leaves were transplanted to 300 $\mathrm{ml}$ plastic cups using the same sterile substrate. On January 11th, 2014, the seedling were transplanted into holes of $30 \times 40 \mathrm{~cm}$ of diameter and depth respectively. The fertilization per hole was based on $2 \mathrm{~kg}$ of organic compost, $100 \mathrm{~g}$ of triple superphosphate, $80 \mathrm{~g}$ of $\mathrm{KCl}$ and $40 \mathrm{~g}$ of urea. The harvest was performed from third to sixth month, when the yielding cycle finished.

The experiment was carried out in randomized block design, with 5 treatments, 3 blocks and 5 plants per plot, which were spaced at $2 \mathrm{~m} \times 2 \mathrm{~m}$. The treatments were $\mathrm{T} 1=$ No staking, $\mathrm{T} 2=\mathrm{A}$ vertical rod, $\mathrm{T} 3=$ A horizontal rod, $60 \mathrm{~cm}$ from the ground, T4= Two horizontal rods, 60 and $120 \mathrm{~cm}$ from the ground, and $\mathrm{T} 5=$ Using horizontal trellises, $80 \mathrm{~cm}$ from the ground. The harvest was done weekly from the fourth to the sixth month, when fruits had yellow pericarp . The traits assessed were number fruit number, fruits length and diameter, seed number per fruit and fruit yield.

The physicochemical composition was performed in Foods and Nutrition Laboratory of INPA. One composite sample of fruits from all treatments was collected in a polyethylene bag and carried to the laboratory. Then 20 healthy fruits were selected and washed in water through immersion in $400 \mathrm{ppm}$ of hypochlorite sodium for 30 minutes. Next, they were washed and submersed in water at $43^{\circ} \mathrm{C}$ for $24 \mathrm{~h}$. Then, fruits were cut in the middle with stainless steel knife and the seeds and pulp separated from the peel. The pulp was isolated from the seeds using electric depulper. Both pulp and skin were dried in a stove with forced air circulation at $60^{\circ} \mathrm{C}$ for $72 \mathrm{~h}$. Then they were grinded and sieved at $1.5 \mathrm{~mm}$ mesh in small polyethylene bags. Centesimal analyses in proteins, carbohydrates, lipids, ashes and moisture content were performed in triplicate for these samples. These analyses followed the recommendations of the Association of Official Analytical Chemist (1995). Agronomical data were analyzed through analyses of variance (ANOVA) and Scott-Knott mean tests $(\mathrm{P}<0.05)$. Laboratory data estimated pulp and peel means and standard deviations. The software used was GENES (CRUZ, 2013).

The fruit yield was significantly affected by system staking and ranged from 0.4 to $1.4 \mathrm{t} \mathrm{ha}^{-1}$ (Table 1). The treatments $\mathrm{T} 5, \mathrm{~T} 4$ and $\mathrm{T} 3$ increased the fruit yield by $300 \%, 200 \%$ and $89 \%$ respectively. However, using horizontal trellises (T5) yielded more than others (Table 1), it was threefold the one, which used no staking system (T1). The second most recommendable one was that with two horizontal rods at 60 and $120 \mathrm{~cm}$ from the ground (T4). The staking using a horizontal rod at $60 \mathrm{~cm}$ from ground (T3) increased fruit yield, but just about $50 \%$ that of T4 and T5. The staking that used a vertical stick was ineffective in increasing the fruit yield. On the other side, the mean Brazilian yield of $P$. edulis is $14.5 \mathrm{tha}^{-1}$ (IBGE, 2014), therefore this wild maracuja bears lower yield potential than that $P$. edulis. These findings suggest the 
genetic improvement would be necessary.

Treatments T5, T4, T3 and T2 increased the number of fruits per plant significantly by $195 \%, 130 \%, 48 \%$ and $92 \%$ respectively. This would indicate that any kind of staking would significantly increase the number of fruits per plant, including the simplest staking with one vertical rod (T2). Nevertheless, horizontal trellises showed to be the most efficient one. Given the yield and number of fruits per plant findings one infers staking to be necessary for farming small-passion fruit, just as it happens with commercial varieties of yellow and purple passion fruit.

A significant increase of fruit yield and number of fruits per plant by stacking (Table 1) may have been related to increased flowers exposure. Being that $\mathrm{T} 5$ exposes more than $\mathrm{T} 4$, and so on $(\mathrm{T} 5>\mathrm{T} 4>\mathrm{T} 3>\mathrm{T} 2>\mathrm{T} 1)$, which would facilitate fecundation by insects (COSTA et al., 2008). This would account for the efficiency of conduction in horizontal trellises to increase the fruits productivity. However, depending on their budget and time to dedicate to the management of this crop, any one of these staking systems, but for the one vertical rod one, could be recommended to the family farmers in the state of Amazonas.

Means multiple comparison tests detected no significant differences $(\mathrm{P} \leq 0.05)$ for fruit traits such as length, diameter, mean mass and seed number per fruit. This would indicate these characters not to be affected by staking. However, the lowest values of these traits were found for the treatment with no staking. Indicating that the lack of staking would tend to diminish fruit size and mass.

It was found that, in general, pulp holds more nutrients than peel does, except for moisture, potassium and iron (Tables 2 and 3). On the other hand, moisture and protein content (67\% and $2.6 \%$, respectively) showed to be similar to those of yellow $(72.2 \%$ and $3 \%)$ (ROMERO-RODRIGUEZ et al., 1994) and purple (72\% and 3.1\%) (SCHOTSMANS; FISCHER, 2011) passion fruit varieties. Small passion fruit exhibited higher lipid content $(4.5 \%)$ than yellow $(0.12 \%)$ (ROMERORODRIGUEZ et al., 1994) and purple (0.07-0.7\%) (SCHOTSMANS; FISCHER, 2011) passion fruit did. Regarding carbohydrates content small passion fruit had a lower amount $(24.3 \%)$ than yellow (38.1\%) and purple (37.1\%) passion fruit did (CHAN et al., 1972).

Considering the macro and microelements one finds sodium, potassium and magnesium contents to have been lower in small passion fruit $(1.15 \mathrm{mg}, 0.68 \mathrm{mg}$ and $0.7 \mathrm{mg}$ ) than in yellow ( $8 \mathrm{mg}, 208 \mathrm{mg}$ and $28 \mathrm{mg}$ ) (ROMERORODRIGUEZ et al. 1994) and purple passion fruit (7$30 \mathrm{mg}, 100-764 \mathrm{mg}$ and 16-29 mg) (SCHOTSMANS; FISCHER, 2011; ZIBADI; WATSON, 2004). Similarly, micronutrients such as zinc, iron and copper $(54.8 \mu \mathrm{g}$, $18.5 \mu \mathrm{g}$ and $4 \mu \mathrm{g}$ respectively) were lower in minipassion fruit than in yellow $(600 \mu \mathrm{g}, 600 \mu \mathrm{g}$ and $200 \mu \mathrm{g})$ (ROMERO-RODRIGUEZ et al., 1994) and purple passion fruit $(100 \mu \mathrm{g}, 1600 \mu \mathrm{g}$ and $100 \mu \mathrm{g})$ (ZIBADI; WATSON, 2004). Therefore, this fruit would have a lower amount of nutrients than commercial passion fruit would.

Fruit peel has proved to be relevant as a source of nutraceuticals in the diet of humans or animals. Thus, the peels of banana (AGAMA-ACEVEDO et al., 2016), mango (JAHURUL et al., 2015), opuntia (KOUBAA et al., 2015), rambutan (WANLAPA et al. 2015), passion fruit (JANEBRO et al., 2008; KULKARNI; VIJAYANAND, 2010) among others, have been utilized. In this study, we have found that in general the pulp holds more nutrients, with higher contents of $\mathrm{K}$ and $\mathrm{Fe}(4.3$ and $42.5 \mu \mathrm{g} / 100 \mathrm{~g})$ (Table 3).

In addition, commercial passion fruit ( $P$. edulis) peel flour presented $9.4 \%$ moisture, $3.9 \%$ protein, $0.3 \%$ lipids, $79.4 \%$ carbohydrates and $6.9 \%$ ash contents (CAZARIN et al., 2014). Yet ,wild maracuja peel displayed $86 \%, 0.5 \%, 0.6 \%, 11.7 \%$ and $1.1 \%$, respectively (Table 2), of the formerly mentioned nutrients. It can be explained on account of making peel flour decreases moisture raising the percentage of nutrients. Despite this, this wild maracuja showed twice the lipids content the commercial passion fruit peel flour did. Hence, this genotype peel flour would have higher lipids content than commercial P. edulis.

All these findings suggest that this wild maracuja (P. foetida) is more productive when staked with horizontal trellises $\left(1.4 \mathrm{tha}^{-1}\right)$, yet its yielding is ten times lower that $P$. edulis. Then, a breeding program must include this genotype an another ones from the same site.

In general, pulp and peel macro and micronutrient content showed to be low relative to the commercial passion fruit (P. edulis). However, the sweet wild maracuja lipid content has shown to be higher both in the peel and pulp. Other comparative studies will be necessary so as to ascertain its acceptability for consumers both in natura and processed foods. 
Table 1- Morphoagronomic features means of wild maracuja (Passiflora foetida L.) grown in different staking systems. Manaus, 2013.

\begin{tabular}{ccccccc}
\hline $\begin{array}{c}\text { Staking } \\
\text { type }\end{array}$ & $\begin{array}{c}\text { Fruit number } \\
\text { per plant }\end{array}$ & $\begin{array}{c}\text { Yield } \\
\left(\mathbf{t ~ h a}^{-1}\right)\end{array}$ & $\begin{array}{c}\text { Fruit length } \\
\mathbf{( c m})\end{array}$ & $\begin{array}{c}\text { Fruit diameter Fruit mean Seed number } \\
\mathbf{( c m )}\end{array}$ & $\begin{array}{c}\text { mass }(\mathbf{g}) \\
\text { per fruit }\end{array}$ \\
\hline $\mathrm{T} 1$ & $97.6 \mathrm{~d}$ & $0.35 \mathrm{~d}$ & $1.86 \mathrm{a}$ & $1.73 \mathrm{a}$ & $1.3 \mathrm{a}$ & $26.6 \mathrm{a}$ \\
$\mathrm{T} 2$ & $187.5 \mathrm{c}$ & $0.40 \mathrm{~d}$ & $1.89 \mathrm{a}$ & $1.77 \mathrm{a}$ & $1.4 \mathrm{a}$ & $30.6 \mathrm{a}$ \\
$\mathrm{T} 3$ & $144.7 \mathrm{c}$ & $0.66 \mathrm{c}$ & $1.94 \mathrm{a}$ & $1.77 \mathrm{a}$ & $1.5 \mathrm{a}$ & $37.3 \mathrm{a}$ \\
$\mathrm{T} 4$ & $224.6 \mathrm{~b}$ & $1.05 \mathrm{~b}$ & $1.89 \mathrm{a}$ & $1.75 \mathrm{a}$ & $1.4 \mathrm{a}$ & $30.2 \mathrm{a}$ \\
T5 & $288.2 \mathrm{a}$ & $1.40 \mathrm{a}$ & $1.92 \mathrm{a}$ & $1.76 \mathrm{a}$ & $1.5 \mathrm{a}$ & $32.3 \mathrm{a}$ \\
\hline Mean & 188.52 & 0.77 & 1.90 & 1.76 & 1.42 & 31.40 \\
CV (\%) & 38.82 & 57.95 & 1.62 & 0.95 & 5.89 & 12.41 \\
\hline
\end{tabular}

Equal letters indicate that there was no significant difference by Skott and Knott test $(\mathrm{P}<0.05)$

Legend: T1 $=$ No staking. T2 $=$ A vertical rod. T3 $=$ A horizontal rod $60 \mathrm{~cm}$ above the ground. T4 $=$ Two horizontal poles 60 and $120 \mathrm{~cm}$ from the ground. Trellis $\mathrm{T} 5=80 \mathrm{~cm}$ from the ground

Table 2- Chemical composition in $100 \mathrm{~g}$ of whole matter of peel and pulp of wild maracuja (Passiflora foetida L.) of the upper Solimões region, Amazonas, Manaus, 2014.

\begin{tabular}{lcc}
\hline \multicolumn{1}{c}{ Component } & Pulp & Peel \\
\hline Moisture $(\mathrm{g})$ & $67.48 \pm 0.29$ & $86.09 \pm 0.11$ \\
Protein $(\mathrm{g})$ & $2.55 \pm 0.05$ & $0.53 \pm 0.00$ \\
Lipids $(\mathrm{g})$ & $4.47 \pm 0.08$ & $0.60 \pm 0.00$ \\
Glycids $(\mathrm{g})$ & $24.26 \pm 0.05$ & $11.68 \pm 0.09$ \\
Ash $(\mathrm{g})$ & $1.24 \pm 0.05$ & $1.09 \pm 0.09$ \\
Calories (kcal) & $147.53 \pm 0.02$ & $54.28 \pm 0.05$ \\
\hline
\end{tabular}

Table 3- Mean concentration values of micro and macro elements in $100 \mathrm{~g}$ of whole matter of peel and pulp of wild maracuja (Passiflora foetida L.) of the upper Solimões region, Amazonas, Manaus, 2014.

\begin{tabular}{|c|c|c|c|c|c|c|c|}
\hline \multicolumn{8}{|c|}{ Peel } \\
\hline Na (mg) & K (mg) & Ca (mg) & Mg (mg) & $\operatorname{Mn}(\mu \mathrm{g})$ & $\mathrm{Zn}(\mu \mathrm{g})$ & $\mathrm{Fe}(\mu \mathrm{g})$ & $\mathrm{Cu}(\mu \mathrm{g})$ \\
\hline 11 & $4.33 \pm 0.15$ & $4.247=$ & $0.68 \pm 0.00$ & $3.81 \pm 0.15$ & $35.90 \pm 0.92$ & $42.46 \pm 1.36$ & $=0.27$ \\
\hline \multicolumn{8}{|c|}{ Pulp } \\
\hline $1.15 \pm 0.01$ & $0.68 \pm 0.01$ & $5.28 \pm 0.60$ & $0.71 \pm 0.01$ & $5.28 \pm 0.17$ & $54.8 \pm 1.47$ & $18.52 \pm 2.3$ & $4.04 \pm 1.08$ \\
\hline
\end{tabular}

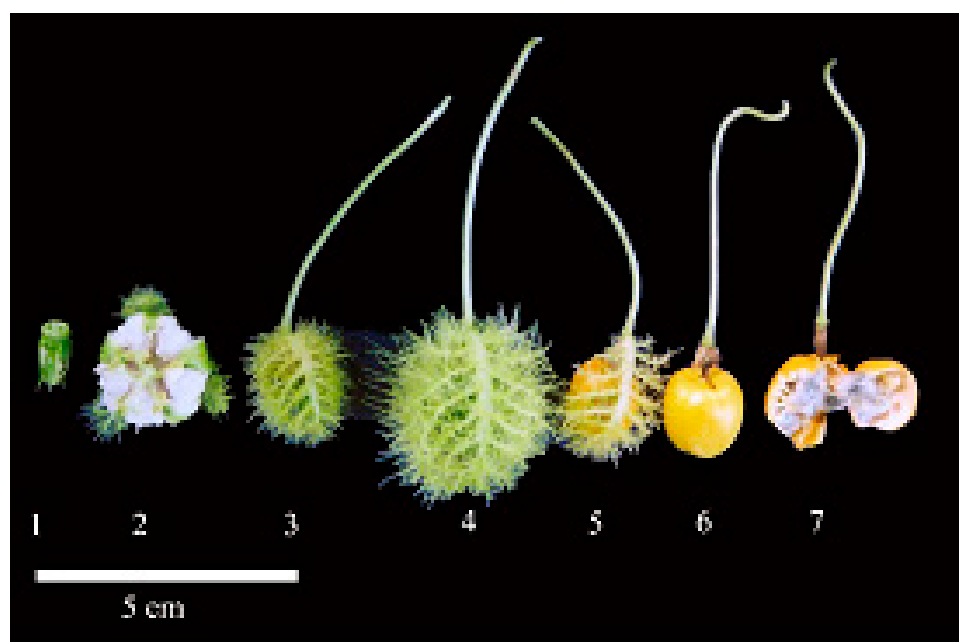

Figure 1- Ripening phases of wild maracuja fruits (Passiflora foetida L.). 1 and 2: flowering phase; 3 to 5: immature fruits; 6 and 7: mature fruits. 


\section{Acknowledgements}

The authors thank the financial support of the INPA, FINEP and FAPEAM.

\section{References}

AGAMA-ACEVEDO, E.; SANUDO-BARAJAS, J.A.; DE LA ROCHA, R.V.; GONZALEZ-AGUILAR, G.A.; BELLO-PEREZ, L.A. Potential of plantain peels flour (Musa paradisiaca L.) as a source of dietary fiber and antioxidant compound. CyTA-Journal of Food, Abindgon, v.14, n.1, p.117-123, 2016.

ALVARES, C.A.; STAPE, J.L.; SENTELHAS, P.C.; GONÇALVES, J.L.M.; SPAROVEK, G. Koppen's climate classification map for Brazil. Meteorologische Zeitschrift, Berlin v.22, n.6, p.711-728, 2013.

AOAC - Association of Official Analytical Chemist. Official methods of analysis. Arlington: AOAC International, 1995.

Association of official analytical chemist. Official methods of analysis. Arlington: AOAC International, 1995.

CERQUEIRA-SILVA, C. B. M.; FALEIRO, F. G.; DE JESUS, O. N.; DOS SANTOS, E. S. L.; DE SOUZA, A. P. The Genetic Diversity, Conservation, and Use of Passion Fruit (Passiflora spp.). In: AHUJA, M. R. e JAIN, S. M. (Ed.). Genetic Diversity and Erosion in Plants: Case Histories. Cham: Springer International Publishing, 2016. p.215-231.

CAZARIN, C.B.B.; DA SILVA, J.K.; COLOMEU, T.C.; ZOLLNER, R.D.; MAROSTICA, M.R. Antioxidant capacity and chemical composition of passion fruit peel (Passiflora edulis). Ciência Rural, Santa Maria, v.44, n.9, p.1699-1704, 2014.

CHAN JR, H.T.; CHANG, T.S.; CHENCHIN, E. Nonvolatile acids of passion fruit juice. Journal of Agricultural Food and Chemistry, Easton, v.20, n.1, p110-112, 1972.

COSTA, A.F.S.; COSTA, A.N.; VENTURA, J.A.; FANTON, C.; LIMA, I.M.; CETANO, L.C.S.; SANTANA, E.N. Recomendações técnicas para o cultivo do maracujazeiro. Vitória: Incaper, 2008.
CRUZ, C.D. GENES - a software package for analysis in experimental statistics and quantitative genetics. Acta Scientiarum, Maringá, v.35, n.3, p.271-276, 2013.

FEUILLET, C.; MACDOUGAL, J.M. Passifloraceae. In: KUBITZKI, K. (ed.). Flowering plants. Eudicots. Heidelberg: Springer, 2007. p.270-281.

IBGE - Instituto Brasileiro de Geografia e Estatística. Produção agrícola municipal. Rio de Janeiro, 2014.

JAHURUL, M.H.A.; ZAIDUL, I.S.M.; GHAFOOR, K.; AL-JUHAIMI, F.Y.; NYAM, K.L.; NORULAINI, N.A.N.; SAHENA, F.; OMAR, A.K.M. Mango (Mangifera indica L.) by-products and their valuable components: A review. Food Chemistry, London, v.183, p.173-180, 2015.

JANEBRO, D.I.; DE QUEIROZ, M.D.R.; RAMOS, A.T.; SABAA-SRUR, A.U.O.; DA CUNHA, M.A.L.; DINIZ, M.D.F.M. Effect of the flour of the yellow passion fruit peel (Passiflora edulis f.flavicarpa Deg.) in the glycemic and lipid levels of type 2 diabetes patients. Revista Brasileira de Farmacognosia, São Paulo, v.18, p.724732, 2008.

KOUBAA, M.; KTATA, A.; BARBA, F.J.; GRIMI, N.; MHEMDI, H.; BOUAZIZ, F.; DRISS, D.; CHAABOUNI, S.E. Water-soluble polysaccharides from Opuntia stricta Haw. fruit peels: recovery, identification and evaluation of their antioxidant activities. International Agrophysics, Lublin, v.29, n.3, p.299-306, 2015.

KULKARNI, S.G.; VIJAYANAND, P. Effect of extraction conditions on the quality characteristics of pectin from passion fruit peel (Passiflora edulis f.flavicarpa L.). LwtFood Science and Technology, Amsterdam, v.43, n .7, p.1026-1031, 2010.

MELETTI, L.M.M.; BRÜCKNER, C.H. Melhoramento genético. In: BRÜCKNER, C.H.; PICANÇO, M.C. (ed.). Maracujá: tecnologia de produção, pós-colheita, agroindústria e mercado. Porto Alegre: Cinco Continentes, 2001. p.345-385.

PURICELLI, L.; DELL'AICA, I.; SARTOR, L.; GARBISA, S.; CANIATO, R. Preliminary evaluation of inhibition of matrix-metalloprotease MMP-2 and MMP9 by Passiflora edulis and P.foetida aqueous extracts. Fitoterapia, New York, v.74, n.3, p.302-304, 2003.

ROMERO-RODRIGUEZ, M.; VAZQUEZ-ODERIZ, M.; LOPEZ-HERNANDEZ, J.; SIMAL-LOZANO, J. Composition of babaco, feijoa, passion-fruit and tamarillo produced in Galicia (NW Spain). Food Chemistry, London, v.49, n.3, p.23-27, 1994. 
SCHOTSMAN, W.C.; FISCHER, G. Passion fruit (Passiflora edulis Sim.). In: YAHIA, E.M. (ed.). Postharvest biology and technology of tropical and subtropical fruits. Cambridge: Woodhead Publishing, 2011.p.125-143e.

WAGNER, W.L.; HERBST, D.R.; SOHMER S.H. Manual of the flowering plants of Hawai'i. Honolulu: University of Hawaii Press \& Bishop Museum Press, 1990.
WANLAPA, S.; WACHIRASIRI, K.; SITHISAM-ANG, D.; SUWANNATUP, T. Potential of selected tropical fruit peels as dietary fiber in functional foods. International Journal of Food Properties, Philadelphia, v.18, n.6, p.1306-1316, 2015.

YOCKTENG, R.; EECKENBRUGGE, G.C.; SOUZACHIES, T.T. Passiflora. In: KOLE, C. (ed.). Wild crop relatives: genomic and breeding resources/tropical and subtropical fruits. Berlin: Springer, 2011. p.129-193.

ZIBADI, S.; WATSON, R.R. Passion fruit (Passiflora edulis): composition, efficacy and safety. Evidence-Based Integrative Medicine, Thousand Oaks, v.1, n. 3, p.183187, 2004. 